\title{
CHANGING TREND OF CAPITAL FLOWS: THE CASE OF INDIA
}

\author{
SHAILESH GANDHI \\ IIM, Ahmedabad, Gujarat, India \\ HEMANTKUMAR P. BULSARA \\ VAISHALI S. DHINGRA \\ S V National Institute of Technology, Gujarat, India
}

\begin{abstract}
Many countries witnessed enormous increases in international capital mobility after globalization. This, in turn, has improved economic integration among emerging economies and developed nations. The trend of these cross country flows of capital discloses that non-debt creating private capital flows are dominating the official flows which come in the form of official grants and private debt flows. Moreover, the portfolio equity investment which shows tremendous growth has exposed individual countries to the risk of improved volatility and sudden stops. These trends, driven by globalization, have enabled the pursuit of higher returns and portfolio diversification as well as market-oriented reforms in many countries which have liberalized access to financial markets. As a new participant in the globalization wave, India went through several structural and policy changes only in the early 1990s. India introduced a New Economic Policy guided by the IMF and the World Bank with the intention of economic stabilization.
\end{abstract}

This paper reviews several literature on fundamental aspects and some former empirical evidence about globalization and capital flows to emerging economies with special reference to India. It also highlights the adverse impact of hot money along with debt flow in India.

Keywords: Globalization, emerging economies, economic integration, capital flows.

\section{Introduction}

From the 1950s onwards there was a tremendous expansion of the international capital markets, goaded partly by the flow of international investments linked to post-war economic recuperation 
and also stimulated by the development of offshore currency markets where financial transactions were subject to much lighter controls. Countries were periodically subjected to pressures due to surges of short-term capital flows between major currencies which eventually swept over the Bretton Woods system of exchange rates where all other currencies were pegged against the US\$. Therefore, problems associated with the financing and payment arrangements of trade and other current-account transactions remained an important concern for the functioning of the international financial system. Thereafter, increased attention has been paid to ways of handling, responding and controlling capital movements, as these have continued to grow in size, unshackled as they increasingly have been, owing to the progressive liberalization of capital-account transactions in various world economies.

A comprehensive description of the main instruments and arrangements for the governance of international capital flows is, of course, impossible in a paper of this length, but a brief sketch of the major features facilitate understanding of the arguments as follows.

The paper is organized as follows: Section 1 details the drivers of globalization around the world. Section 2 is about the indicators of globalization and economic integrations. The trend of capital flows to Emerging Market Economies (EMEs) especially in India is described in Section 3 and Section 4 respectively. Section 5 postulates the ways to manage capital inflows and Section 6 concludes.

\section{Inception of Globalization}

Globalization refers to the increasing unionization of the world's economies through the reduction of international trade barriers such as tariffs, export fees and import quotas and increase in the financial flows through mutual exchange of technology and knowledge. The underlying objective is to increase material wealth, goods, and services through an international division of labour and catalysing efficiencies by international relations, specialization and competition. It describes the process by which regional economies, societies, and cultures have become integrated through communication, transportation, trade and technology. In the context of economy, globalization refers to increasing economic interdependence and integration of national economies across the world through an intensifying pressure for cross-border movement of goods, services, technology, capital, migration and military presence (Bhagwati, 2004). 
The seeds of globalization were sowed many centuries ago. But the $19^{\text {th }}$ century is termed as the modern era for globalization. After industrialization in the $18^{\text {th }}$ century, world economies started moving towards the technological innovations in terms of product and process innovations. Production became the heart of any country; people became aware of cheap labour and economies of scale. This increased efficiency and production paved way for globalization. People started hunting for new markets to expand their business locally and internationally. Since about 1980 there has been unprecedented global economic integration. The World Bank report entitled "Globalization, Growth and Poverty" divided the evolution of Globalization into three main time zones termed as waves.

The period during 1817-1940 has been categorized as the first wave of globalization and expansion of international trade. National companies started spreading their business in external markets with the rapid development of transportation. The actors involved in this process were the European imperial powers, the colonies and the United States of America. During the economic crises of World War I and World War II, the inclination of national economies towards expansion collapsed totally. (Figure 1).

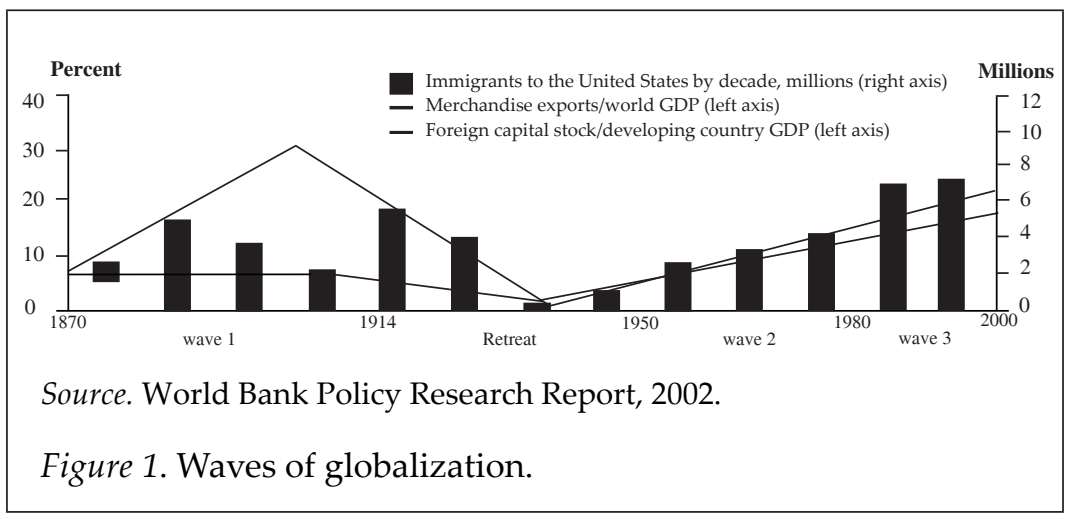

The second stage of globalization took place during 1945-1980 and was characterized by the liberalization of the international trade under the General Agreement on Tariffs and Trade (GATT) influence. GATT was initially founded as a part of the plan for economic recovery after World War II in order to create an optimal environment for the expansion of international trade through the reduction of tariffs. For the first time, international specialization within manufacturing became important, allowing agglomeration and scale economies to 
be realized. This helped to drive up the incomes of the rich countries relative to the rest. The second wave introduced a new type of trade; rich countries specialized in manufacturing niches that gained productivity from agglomerated clusters through horizontal linkages or vertical expansions. Most of the trade among developed countries were determined not by comparative advantage based on differences in factor endowments but by cost savings from agglomeration and scale. During the second wave of globalization, most developing or emerging economies did not participate in the growth of global manufacturing and services trade; even by 1980 only 25 per cent of the merchandise exports of developing countries were manufactured goods (Rădescu, 2008).

The third stage of the globalization process began in 1980 and has continued until the present. It is characterized by an accentuated development of the telecommunications and huge progresses in the exploration of the cosmic space. This period is often called "economy without borders", because modern technology increased the speed of the long-distance financial trades. In January, 1995 the World Trade Organization (WTO) was created and it became the successor of GATT. During the new era of globalization developing countries came up as global markets for developed nations and were relegated to an outer edge in the world economy. Their income started showing a downward trend and poverty started growing. International migration and capital flows became fairly large during the new wave of globalization.

The most effective transformation during the new age of globalization was the sharp increase in the export of manufactured products from 25 per cent in 1980 to 80 per cent in 1998. According to Davis and Weinstein (2003) the export of the developing countries was labour intensive indeed. Another important transformation was the increase in the export of services; during 1980 the export of commercial services was 17 per cent for developed nations and 9 per cent for developing nations which rose up to 20 per cent i.e. an increase of 16 per cent for developed nations whereas it doubled and rose up to 17 per cent for developing nations.

\section{Globalization and India}

India opened up its economy far after China, Indonesia, Malaysia, Hong Kong and Singapore, slowly and gradually as compared to other developing economies. The awareness about the need to open 
up the country's borders started in the late 1980s when the $6^{\text {th }}$ Prime Minister, late Mr. Rajiv Gandhi, was at the reins of policy design. An unprecedented drought, doubling of global oil prices, mounting fiscal deficits, ever-increasing non-plan expenditure, loss-making public sector undertakings, and the worsening current account deficits continued to be areas of serious concern and put a severe strain on the country's economic fabric. Foreign investors and NRIs had lost confidence in the Indian economy. Capital was flying out of the country and it was close to defaulting on loans. Along with these bottlenecks at home, many unforeseeable changes swept the economies in Western and Eastern Europe, South East Asia, Latin America and elsewhere, around the same time. These were the economic compulsions at home and abroad that called for a complete overhauling of our economic policies and programmes. In June of 1991, when the current Prime Minister, Dr. Manmohan Singh, was the Finance Minister (and Mr. Narasinha Rao was the Prime Minister), the country received the first significant shock of globalization and liberalization.

Far reaching meaningful changes in trade and exchange rate policies, viz. two bouts of devaluation of the rupee, phased reduction in import tariffs, quantitative restrictions, quota except on consumer goods, the suspension of cash compensatory support of exports, trimming and rationalizing the structure of mounting export subsidies, full convertibility of the rupee on current account on balance of payment in 1993, moving from a dual exchange rate system in 1992 to a single market determined unified exchange rate system, have been made (Aggarwal, 2005; Kumar, Palit, \& Singh, 2007).

Table 1

Macroeconomic Performance in Post 1991 Years

\begin{tabular}{ccccc}
\hline Year & $\begin{array}{c}\text { Real GDP } \\
\text { Growth }\end{array}$ & $\begin{array}{c}\text { Inflation } \\
\text { Rate }\end{array}$ & $\begin{array}{c}\text { Interest } \\
\text { Rate }\end{array}$ & $\begin{array}{c}\text { Money Supply } \\
\text { (Billions of Rs.) }\end{array}$ \\
\hline 1991 & 0.96 & 8.9 & 17.88 & 1046.1 \\
1992 & 2.3 & 13.7 & 18.92 & 1120.9 \\
1993 & 1.5 & 10.1 & 16.25 & 1330.2 \\
1994 & 5.9 & 8.4 & 14.75 & 1695 \\
1995 & 7.3 & 10.9 & 15.46 & 1883.5 \\
1996 & 7.3 & 7.7 & 15.96 & 2148.9 \\
\hline & & & & (continued)
\end{tabular}




\begin{tabular}{ccccc}
\hline Year & $\begin{array}{c}\text { Real GDP } \\
\text { Growth }\end{array}$ & $\begin{array}{c}\text { Inflation } \\
\text { Rate }\end{array}$ & $\begin{array}{c}\text { Interest } \\
\text { Rate }\end{array}$ & $\begin{array}{c}\text { Money Supply } \\
\text { (Billions of Rs.) }\end{array}$ \\
\hline 1997 & 7.8 & 6.4 & 13.83 & 2419.3 \\
1998 & 6.5 & 4.8 & 13.54 & 2703.5 \\
1999 & 6.5 & 6.9 & 12.54 & 3161.2 \\
2000 & 6.1 & 3.3 & 12.29 & 3495.9 \\
2001 & 4 & 7.1 & 12.08 & 3846 \\
2002 & 6.2 & 4.7 & 11.92 & 4318.6 \\
2003 & 5.5 & 5.1 & 11.5 & 5025.98 \\
2004 & 8 & 4.5 & 10.6 & 6067.65 \\
2005 & 7.5 & 3.7 & 9.37 & 7212.94 \\
2006 & 9.5 & 4.3 & 8.9 & 8597.17 \\
2007 & 9.5 & 9.6 & 8.91 & 9889.89 \\
2008 & 9.8 & 8.3 & 8.37 & 11030.22 \\
2009 & 6.6 & 11 & 9.25 & 12991.16 \\
2010 & 7.9 & 12.7 & 11.25 & 15241.18 \\
\hline
\end{tabular}

Source. Some figures are from IMF's publication, International Financial Statistics Yearbook, 2003, Union Budget and Economic Survey, 2010-2011, Government of India and World Development Indicators, World Bank.

The post reform years showed a quick and efficient recovery from the acute macroeconomic crisis of 1991. The real GDP in the 1990s increased at an annual rate of 6 per cent which was even more impressive because the rest of the world was going through a minor recession. The highest increase in real GDP was experienced in 200708 at 9.8 per cent. And it is a proven fact that increased production and large capital inflow had its effect on the prices; thus the inflation rate of 13.6 per cent in 1991 was reduced to 3.3 per cent in 19992000, a remarkable achievement by any standard. The monetary policy was carried out responsibly and the fiscal pressures were negative but much more manageable than earlier years. In the first 3 years of the 1990s the economic hardships continued partly due to the increased oil price and overall recessionary forces, coupled with political instability, lack of technological innovation, and a poor monsoon. The increased international trade, free economy, technological improvements prompted by tremendous growth in information technology and many such efficient factors combined to show positive effects from 1994. Liberalization, at least partially, has become effective in attracting foreign direct investment and providing a positive outlook for the Indian economy and overall excitement amongst producers and investors. 


\section{Indicators of Economic Integration and Globalization}

The economic integration can be evaluated through three different indicators, (1) Trade of goods and services (2) Migration of people and (3) Capital flows.

\section{Trade}

Trade as a proportion of GDP in the year 1975 was only 12 per cent. Before globalization, that began in 1991, India's total trade (non-oil) did not show any comparable growth and remained nearly at 13 per cent, but after 1991 there was a sharp increase in the total trade (nonoil) at an average of 17 per cent compounded annual growth rate. In 2010 the proportion of total trade to GDP was almost three times the proportion in 1991. (Refer Table 2). This evaluation was just to show that India was moving towards more and more integration. The fast increase in the total trade after 1991 was due to the increasing share of service export which made India an important service exporter along with China. So, in recent times the fate of India is attached to the fate of other world economies.

Table 2

India's Foreign Trade in Goods and Services as a Share of GDP (\%)

\begin{tabular}{cccccccc}
\hline Year & Import $\%$ & Export \% & $\begin{array}{c}\text { Total } \\
\text { Trade }\end{array}$ & Year & Import \% & Export \% & $\begin{array}{c}\text { Total } \\
\text { Trade }\end{array}$ \\
\hline 1975 & 6.73 & 5.71 & 12.44 & 1993 & 9.93 & 9.95 & 19.88 \\
1976 & 6.19 & 6.76 & 12.95 & 1994 & 10.31 & 10.00 & 20.31 \\
1977 & 6.34 & 6.46 & 12.80 & 1995 & 12.16 & 10.97 & 23.13 \\
1978 & 6.67 & 6.39 & 13.05 & 1996 & 11.68 & 10.51 & 22.19 \\
1979 & 8.26 & 6.83 & 15.09 & 1997 & 12.07 & 10.82 & 22.89 \\
1980 & 9.35 & 6.21 & 15.56 & 1998 & 12.83 & 11.15 & 23.98 \\
1981 & 8.67 & 6.00 & 14.67 & 1999 & 13.61 & 11.66 & 25.28 \\
1982 & 8.24 & 6.05 & 14.29 & 2000 & 14.15 & 13.23 & 27.38 \\
1983 & 7.94 & 5.91 & 13.85 & 2001 & 13.65 & 12.76 & 26.41 \\
1984 & 7.82 & 6.36 & 14.17 & 2002 & 15.48 & 14.49 & 29.97 \\
1985 & 7.73 & 5.31 & 13.05 & 2003 & 16.10 & 14.80 & 30.90 \\
\hline & & & & & & (continued)
\end{tabular}




\begin{tabular}{cccccccc}
\hline Year & Import \% & Export \% & $\begin{array}{c}\text { Total } \\
\text { Trade }\end{array}$ & Year & Import \% & Export \% & $\begin{array}{c}\text { Total } \\
\text { Trade }\end{array}$ \\
\hline 1986 & 7.10 & 5.25 & 12.36 & 2004 & 19.31 & 17.55 & 36.86 \\
1987 & 7.06 & 5.67 & 12.73 & 2005 & 22.03 & 19.28 & 41.32 \\
1988 & 7.54 & 6.10 & 13.64 & 2006 & 24.32 & 21.27 & 45.59 \\
1989 & 8.25 & 7.10 & 15.34 & 2007 & 24.46 & 20.43 & 44.90 \\
1990 & 8.55 & 7.13 & 15.68 & 2008 & 28.91 & 23.48 & 52.39 \\
1991 & 8.59 & 8.59 & 17.18 & 2009 & 24.02 & 19.58 & 43.61 \\
1992 & 9.70 & 8.94 & 18.64 & 2010 & 24.86 & 18.47 & 43.32 \\
\hline
\end{tabular}

Source. Global Indicators, World Bank.

\section{Migration of People}

Almost 3 per cent of the world's population or about 190 million people live outside the land of their birth. These migrants bring energy, entrepreneurship and fresh ideas to their societies. Displacement caused by World War II and its ripple effects were very large as migration had continued at a high rate. But the $20^{\text {th }}$ century experienced a totally different picture as reactions against migrants set in by the mid-1970s with the result that highly restrictive laws closed the borders. Literature shows that the number of legal migration has decreased, although illegal migration continued to flow across porous borders in great numbers. The United States, Europe, Australia and Japan encouraged elite migration, seeking highly educated people in the midst of specialized hi-tech skills. (Keeley, 2009).

\section{Capital Flows}

External finance for developing countries can come from one of the following four sources: (a) Official loans and grants, (b) external debt, (c) foreign direct investment (FDI), and (d) foreign portfolio investment (FPI) (Kant, 2010).

\section{Official loans and grants}

To meet the Millennium Development Goals, including cutting global poverty in half by 2015, donor countries have been called upon to allocate 0.7 per cent of their GNP for official development assistance, but this raised the question of what form the aid should take-loans or grants? Some recent initiatives have called for a shifting of foreign 
aid toward grants, while increasing overall assistance to developing countries. These initiatives are driven, particularly, by the belief that excessive lending has led to massive debt accumulation in many developing countries and has not helped them reach their development objectives. From this perspective, aid should be motivated primarily by humanitarian objectives, and thus should take the form of grants. It is thought that such an approach would help the recipient countries to develop their economies and improve their prospects for achieving debt sustainability. In response to these initiatives, some donor countries and researchers have expressed concern that a significant shift to grants, would make it difficult for the International Development Association, the World Bank's concessional lending arm to maintain lending at the existing level. They also fear that such a shift could dampen public support in donor countries for transferring aid to developing countries (Clements \& Gupta, 2004).

\section{External debt}

External debt is a private debt including commercial bank loans, bonds issued by developing countries' entities/institutions in developed countries and export credits. External debt (or foreign debt) is that part of the total debt in a country that is owed to creditors outside the country. The debtors can be governments, corporations or private households. The debt includes money owed to private commercial banks, other governments or international financial institutions such as the International Monetary Fund (IMF) and the World Bank.

The World Bank and IMF hold that "a country can be said to achieve external debt sustainability if it can meet its current and future external debt service obligations in full, without recourse to debt rescheduling or the accumulation of arrears and without compromising growth". There are various indicators for determining a sustainable level of external debt. Each has its own advantage and peculiarity to deal with particular situations. There is no unanimous opinion amongst economists as to one sole indicator. These indicators are primarily in the nature of ratios i.e. comparison between two heads and the relation thereon and thus facilitate the policy makers in their external debt management exercise. These indicators can be thought of as measures of the country's "solvency", in that they consider the stock of debt at a certain time in relation to the country's ability to generate resources to repay the outstanding balance. 
Examples of debt burden indicators include the (a) debt to GDP ratio, (b) foreign debt to exports ratio, (c) government debt to current fiscal revenue ratio etc. This set of indicators also cover the structure of the outstanding debt including the (d) share of foreign debt, (e) short-term debt, and (f) concessional debt in the total debt stock (Siripala \& Perera, 2003). A second set of indicators focuses on the short-term liquidity requirements of the country with respect to its debt-service obligations. These indicators are not only useful as early-warning signs of debt service problems, but also highlight the impact of the inter-temporal trade-offs arising from past borrowing decisions. Examples of liquidity monitoring indicators include the (a) debt service to GDP ratio, (b) foreign debt service to exports ratio, (c) government debt service to current fiscal revenue ratio etc. The final indicators are more forward looking as they point out how the debt burden will evolve over time, given the current stock of data and average interest rate. The dynamic ratios show how the debt burden ratios would change in the absence of repayments or new disbursements, indicating the stability of the debt burden. An example of a dynamic ratio is the ratio of the average interest rate on outstanding debt to the growth rate of nominal GDP (IMF, 2003; Ghosh et al., 2005).

\section{Foreign direct investment}

Foreign direct investment (FDI) refers to the net inflows of investment to acquire a lasting management interest (10 per cent or more of voting stock) in an enterprise operating in an economy other than that of the investor (World Bank, 2002). It is the sum of equity capital, reinvestment of earnings, other long-term capital, and short-term capital as shown in the balance of payments. It usually involves participation in management, joint-venture, transfer of technology and expertise. There are two types of FDI: inward foreign direct investment and outward foreign direct investment, resulting in a net FDI inflow (positive or negative) and "stock of foreign direct investment", which is the cumulative number for a given period. Direct investment excludes investment through purchase of shares. FDI is one example of international factor movement. FDI is a measure of ownership of productive assets, such as factories, mines and land by overseas investors. Increasing foreign direct investment can be used as one of the measures for growing economic globalization. 


\section{Foreign institutional investments}

Institutional investors are organizations which pool large sums of money and invest those sums in securities, real property and other investment assets. They can also include operating companies which decide to invest their profits to some degree in these types of assets. In economics, foreign portfolio investment is the entry of funds into a country, where foreigners make purchases in the country's stock and bond markets, sometimes for speculation (Sullivan \& Sheffrin, 2003). It is usually a short term investment (sometimes less than a year, or with involvement in the management of the company), as opposed to the longer term foreign direct investment partnership (possibly through joint venture), involving transfer of technology and "know-how".

\section{Capital Flows to Emerging Economies}

Emerging market economies face different challenges, one of which is handling capital flows. Fundamentally attractive prospects in emerging market economies (EMEs) together with low interest rates in advanced economies are likely to lead the continuing net capital inflows and exchange rate pressure in many emerging market economies. This is a desirable process as it is a part of the global rebalancing that must take place if the world economy is to get back to health. At the same time, capital flows can be volatile, making macroeconomic arrangement more difficult. So, capital flows can be termed as two sides of a coin, the challenge for recipient countries is to accommodate the underlying trends while reducing the volatility of the flows when they endanger macroeconomic or financial stability.

International capital flows have been considered as an unprecedented roller-coaster ride in recent times. The Gross inflows dropped drastically as an aftermath of a remarkable surge in the run-up to the global crisis (Milesi-Ferretti \& Tille, 2010), but soon regained their upward momentum (Figure 2). For emerging market economies (EMEs), the volatility in net flows was much acute compared to developed or advanced economies (AEs). In the former, gross inflows and net flows both fell dramatically during the crisis and rebounded sharply afterwards. By contrast, in AEs, gross outflows largely offset gross inflows, generating smoother movements in net flows (Figure 3). 


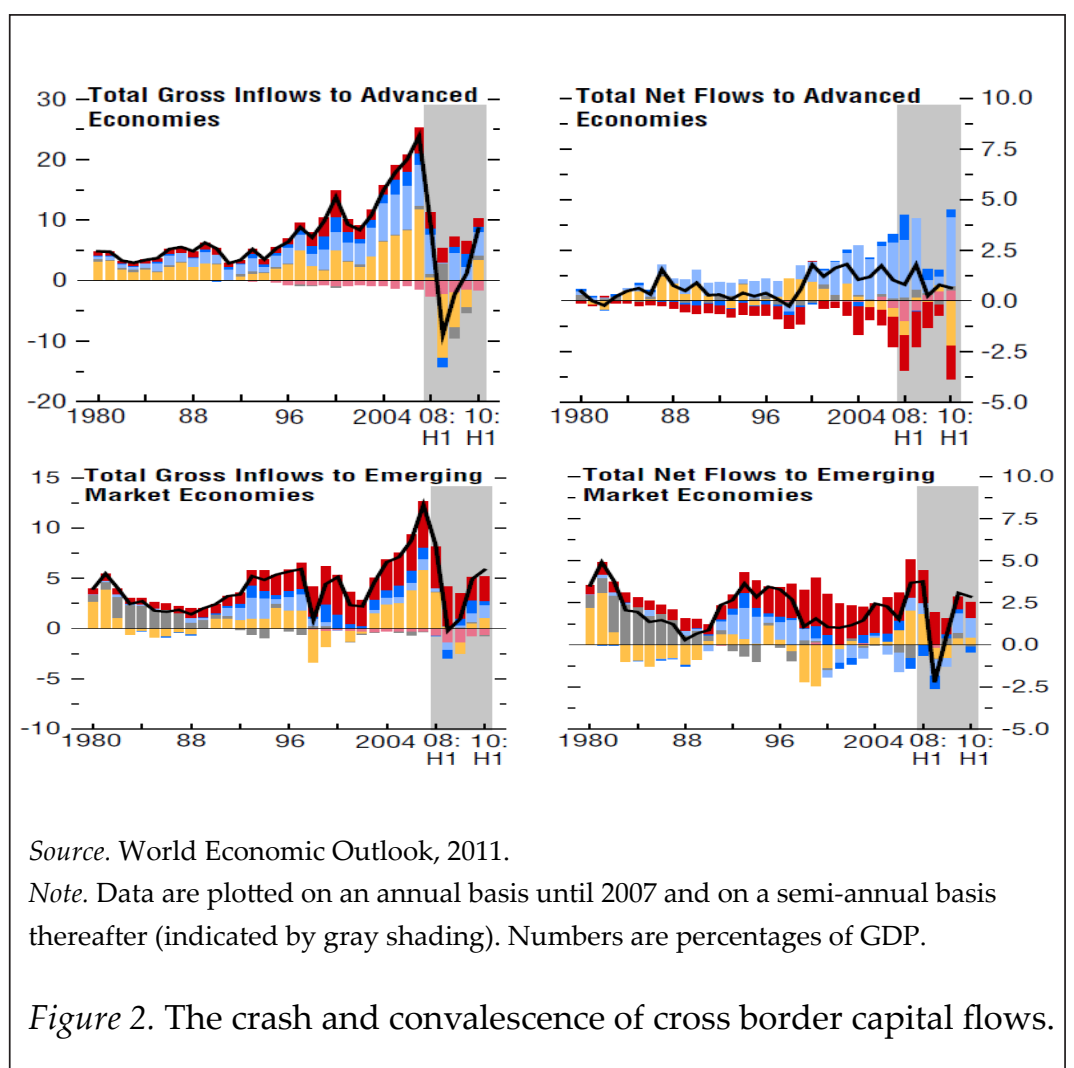

For many EMEs, net flows in the first few quarters of 2010 had already surpassed the averages achieved during 2004-07, but were still lower than their pre-crisis highs. Policymakers in many EMEs have eyed the recent flip-flop in capital flows with mixed reactions. Although external capital can provide the financing and stimulate the currency appreciation needed to strengthen domestic demand in recipient economies, net flows may increase or decrease at a rate that policy makers find difficult to manage or they may fluctuate unpredictably, aggravating domestic economic or financial boombust cycles. Accordingly, a key question confronting policymakers is what would be the scenario as EMEs have lower absorption capacity or what will happen to capital flows when easy global financing conditions characterized by low global interest rates and low risk aversion come to an end. Will capital flows invert with the recommencement of monetary tightening in the United States or in other major AEs? 


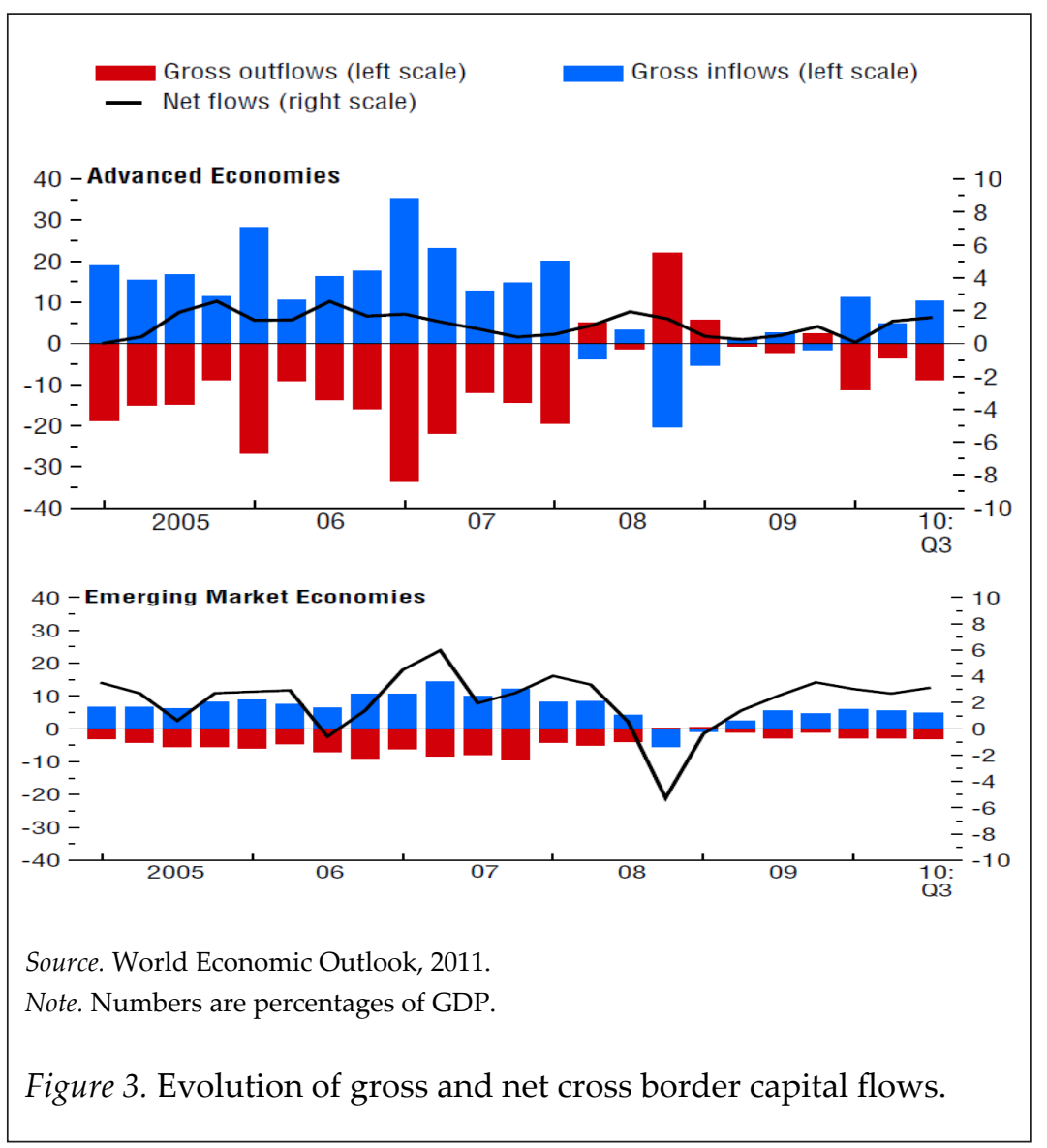

The recovery of capital flows has gained momentum in the post-crisis period. All EMEs experienced a sharp recovery in net flows in an exorbitantly short span of time. The composition of the upsurge is somewhat different, however, with a higher share of debt-creating flows (e.g. foreign portfolio investment) and a lower share of foreign direct investment (FDI) compared with historical trends. The recovery was stronger in larger economies, pulling up the regional aggregates. Net flows ascended in a fairly broad-based manner to emerging Asia and the newly industrialized Asian economies; however, the experience was mixed for Latin America and other emerging economies. If we look at the composition, the recovery in capital flows was primarily driven by portfolio debt flows, but for emerging Asia and Latin America it was also driven by expansion in bank and other private flows (Figure 4). 
If the recent pattern continues, it would imply a shift away from the historical trend of a declining share of debt-creating flows, especially bank and other private flows have fallen over the past three decades for all economies. This suggests, particularly, a natural shift toward nonbank means of financing as a result of deepening domestic capital markets and greater financial linkages and integration. Although, the share of portfolio debt did increase over time, this did not offset the decline in bank and other private flows until after the global crisis.

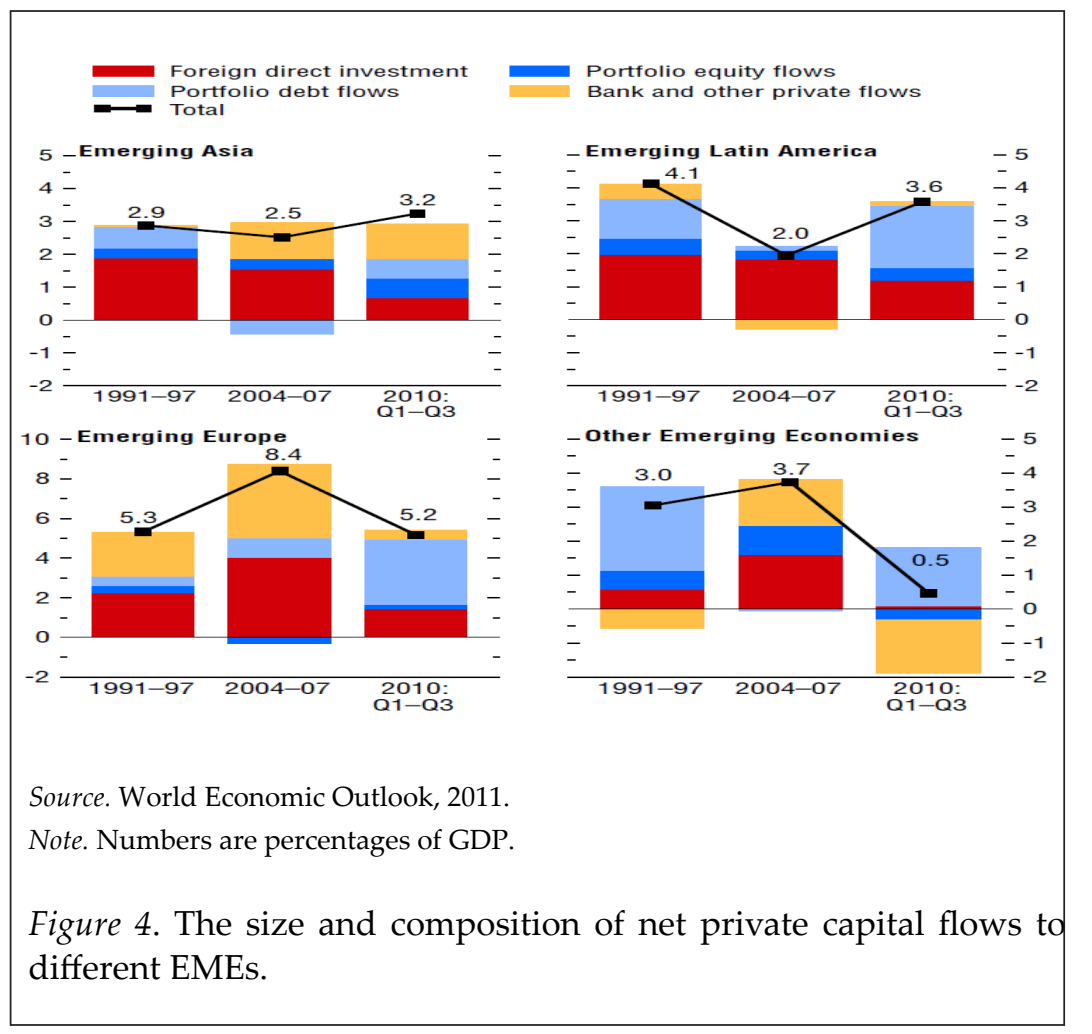

The previous explanation and figures depict that net flows have become slightly more volatile for all economies over time. They also exhibit low constancy. The volatility of net flows is generally higher in EMEs and other developing economies than in AEs. By contrast, there are no obvious differences in the persistence of net flows across economies. Bank and other private flows have typically been the most volatile, and portfolio debt the least persistent. FDI is only slightly more stable and persistent than debt-creating flows to EMEs. 
The variation in capital flows can be explained either by global factors (common factors) or by regional factors (economy specific factors). A large or growing share of the total variation of net flows explained by common factors would imply that capital flows are increasingly determined outside the domestic economy. It has been seen that in EMEs the share of variation in capital flow movements explained by common factors was higher in past two decades. By contrast, for AEs, the share explained by common factors was much smaller in the past decade. The relative importance of regional factors has increased since the mid-1990s within the set of common factors in EMEs. This could be related to the widespread liberalization of capital accounts in many EMEs during the 1990s, increasing cross-border financial links within emerging Europe since the mid-1990s, the subsequent Asian crisis in the late 1990s, and the overall upsurge in global capital flows since the 1990s, which has had a strong regional component. In a nutshell, unlike AEs, common factors appear to be more important for EMEs (IMF, 2013).

\section{Capital Flows to India}

Despite the sharp growth in the extent of financial linkages during the last two decades, India has not kept pace with other emerging markets. Capital account liberalization has been primarily determined using two kinds of measures. One set of measures looks at the de jure openness and focuess on laws governing the movement of capital in and out of the country. Several studies e.g. Chinn and Ito (2008) and Edwards (2007) have used these scores to create an index of capital account openness. It is evident that over the last 40 years there has been an increase in the extent of capital account openness, reflected in the upward shift of the median line. However, India has not liberalized at the same trend resulting in a shift from being in the middle of the distribution of countries which are ranked according to their openness during the 1970s and the 1980s, towards the more restrictive end of the spectrum in the last two decades.

Second, the de facto measures focus on an outcome-based measure of financial integration. These measures involve sums of gross flows or gross stocks of foreign assets and liabilities as a ratio of GDP to indicate the extent of risk sharing. A few de facto measures including those of Kose, Prasad and Terrons (2008) and Lane and Milessi-Ferreti (2007) are available. According to the de facto measures too, India has been at the lower end of the spectrum. Based on the Lane and 
Milessi- Ferreti measure, the ratio of foreign assets and liabilities to GDP, most of the Latin American as well as East Asian countries have experienced greater degrees of integration as compared to India. Yet China, which was lagging behind India during 1980, has overtaken her during the last two decades.

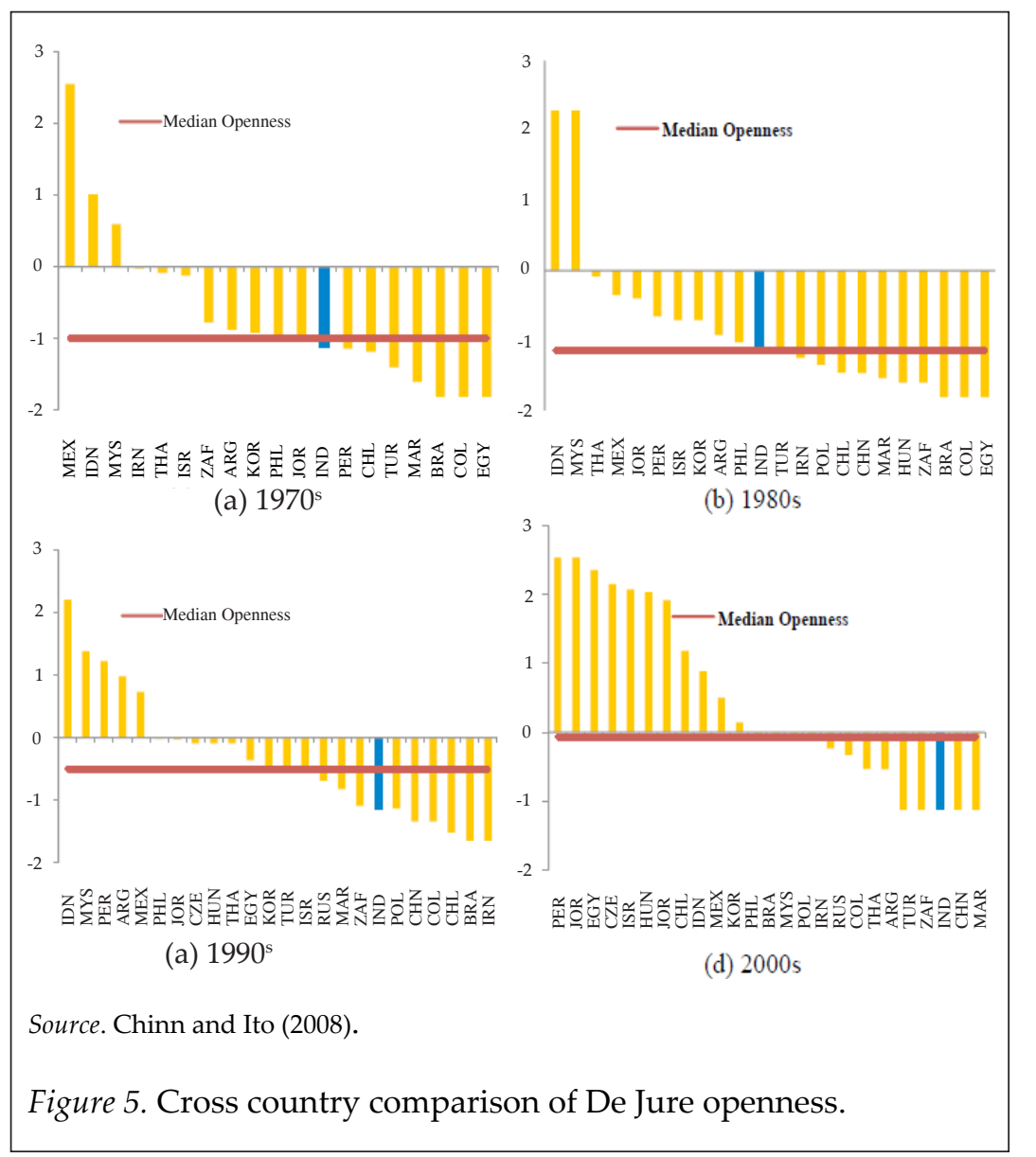

Studies such as Kose et al. (2007) find that stocks of FDI and portfolio liabilities are colligated with better risk-sharing outcomes while stocks of external debt liabilities are not. Moreover, the nondebt flow tends to be more stable than debt flows. Keeping in mind the above argument one can comment that the liberalization of capital flows in India has resulted in altering India's composition of external liabilities in a desired manner. From comprising 95 per cent of India's 
total external liabilities in 1990, the portion of debt liabilities dropped to 33.2 per cent in 2007. Over the same period the share of portfolio liabilities increased from less than 1per centto nearly 50 per cent, while that of FDI increased from 4 per cent to 17.2 per cent (Abhijit \& Rajeswari, 2013). This is evident from Figure 7. The change in the composition of external flows in India towards non-debt creating flows has been in line with international experience.

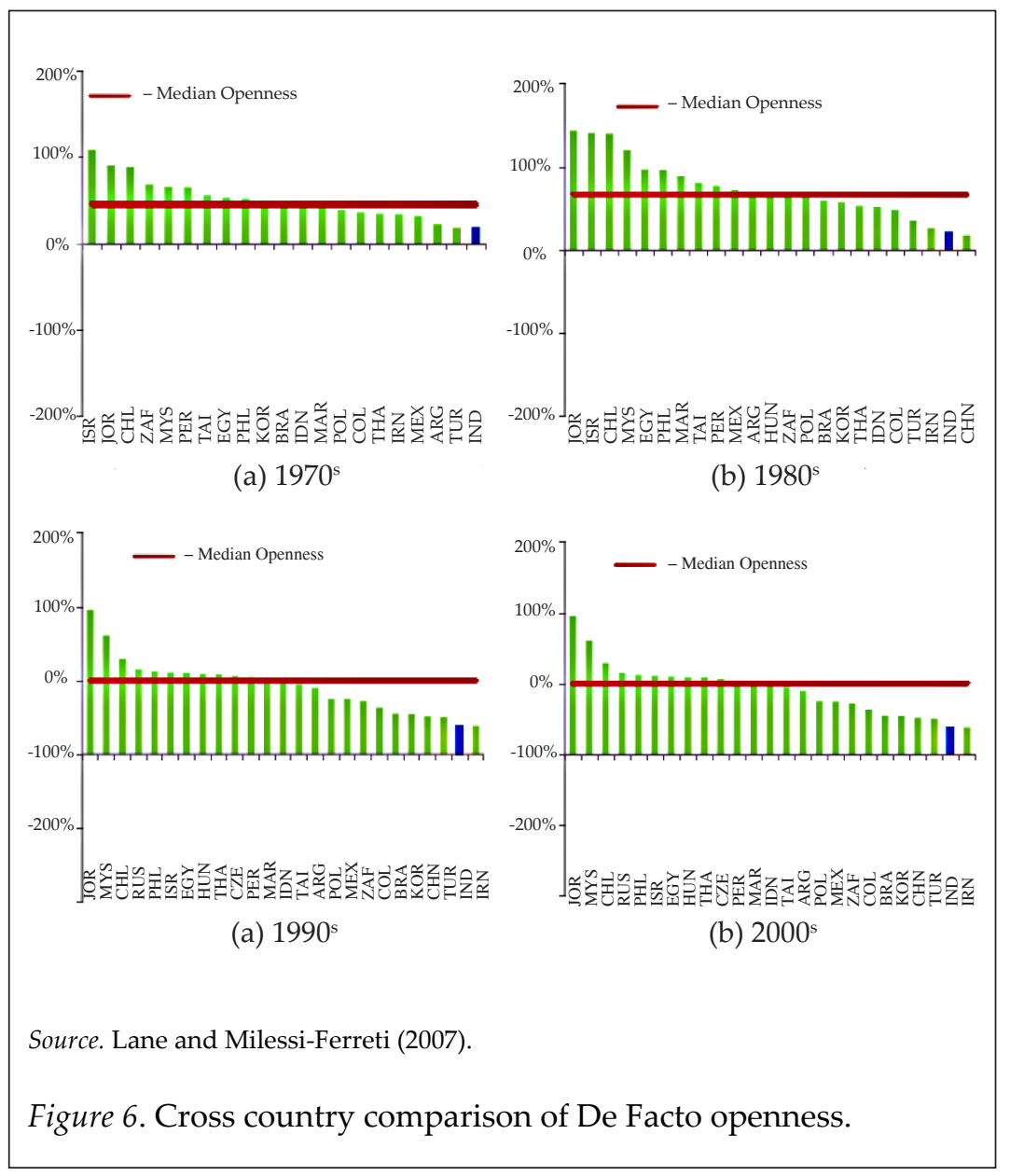

Since the introduction of the reform process in 1990-1991, India has witnessed a significant increase in cross-border capital flows during the previous two decades. Net capital inflows increased from $\$ 7.1$ billion in 1990-91 to $\$ 34.91$ billion in 2010-11 and it was the highest 
at $\$ 108.0$ billion during 2007-08. India has one of the highest net capital flows among the emerging market economies (EMEs) of Asia Mohan, 2008).

\section{Table 3}

External Financing in India (US \$ millions)

\begin{tabular}{|c|c|c|c|c|c|c|c|c|c|}
\hline Item & 1990-91 & $2000-01$ & 2003-04 & 2005-06 & 2006-07 & $2007-08$ & 2008-09 & $\begin{array}{l}2009- \\
10 P R\end{array}$ & $\begin{array}{c}\text { 2010-11P } \\
\text { (Apr.-SEWP) }\end{array}$ \\
\hline Current Account Balance & $-9,680$ & $-2,666$ & $-9,902$ & $-44,383$ & $-9,565$ & $-15,737$ & $-27,915$ & $-38,383$ & $-27,881$ \\
\hline Net Capital Flows of which & 7,188 & 8,535 & 16,736 & 24,954 & 46,171 & 107,901 & 7,835 & 51,824 & 34,911 \\
\hline \multicolumn{10}{|l|}{ 1. Foreign Direct Investment } \\
\hline Inflows & 107 & 4,031 & 4,464 & 8,692 & 22,826 & 34,844 & 37,837 & 37,762 & 15,984 \\
\hline Outflows & 10 & & 2,076 & 61 & 87 & 116 & 166 & 4,638 & 3,399 \\
\hline Net & 97 & 4,031 & 2,388 & 8,901 & 22,739 & 34,728 & 37,672 & 33,124 & 12,585 \\
\hline \multicolumn{10}{|l|}{ 2. Foreign Portfolio Investment } \\
\hline Inflows & 6 & 13,619 & 28,218 & 68,120 & 109,534 & 233,564 & 128,511 & 159,897 & 103,078 \\
\hline Outflows & & 10,859 & 16,862 & 55,626 & 102,530 & 206,294 & 142,635 & 127,521 & 79,174 \\
\hline Net & 6 & 2,760 & 11,356 & 12,494 & 7,004 & 27,270 & $-13,854$ & 32,376 & 23,904 \\
\hline \multicolumn{10}{|l|}{ 3. External Assistance } \\
\hline Inflows & 3,397 & 2,941 & 3,350 & 3,607 & 3,747 & 4,217 & 5,160 & 5,846 & 4,395 \\
\hline Outflows & 1,187 & 2,514 & 6,208 & 1,841 & 1,960 & 2,098 & 2,375 & 2,585 & 1,390 \\
\hline Net & 2,210 & 427 & $-2,858$ & 1,766 & 1,787 & 2,119 & 2,785 & 3,261 & 3,005 \\
\hline \multicolumn{10}{|c|}{ 4. External Commercial Borrowings } \\
\hline Inflows & 4,252 & 9,621 & 5,228 & 14,343 & 20,257 & 28,700 & 13,226 & 13,980 & 10,149 \\
\hline Outflows & 2,004 & 5,313 & 8,153 & 11,835 & 3,814 & 6,060 & 6,578 & 10,641 & 3,858 \\
\hline Net & 2,248 & 4,308 & $-2,925$ & 2,508 & 16,443 & 22,640 & 6,648 & 3,339 & 6,291 \\
\hline \multicolumn{10}{|l|}{ 5. NRI Deposits } \\
\hline Inflows & 7,348 & 8,988 & 14,281 & 17,835 & 19,914 & 29,400 & 37,147 & 41,356 & 22,924 \\
\hline Outflows & 5,811 & 6,672 & 10,639 & 15,046 & 15,593 & 29,222 & 32,858 & 38,432 & 20,761 \\
\hline Net & 1,537 & 2,316 & 3,642 & 2,789 & 4,321 & 178 & 4,289 & 2,924 & 2,163 \\
\hline
\end{tabular}

Source. Reserve Bank of India.

After the balance of payment crisis the motive of the policy reform in India was to encourage non-debt-creating flows and discourage short-term debt flows. The composition of capital inflows to India clearly reflects a shift towards non-debt-creating flows. The significant contribution of external aid towards the capital account during 195080 has dwindled steadily since the 1990s (excluding IMF loans in 1991 and 1992) as the official flows started to be replaced by private equity flows and external commercial borrowing (Figure 7). 


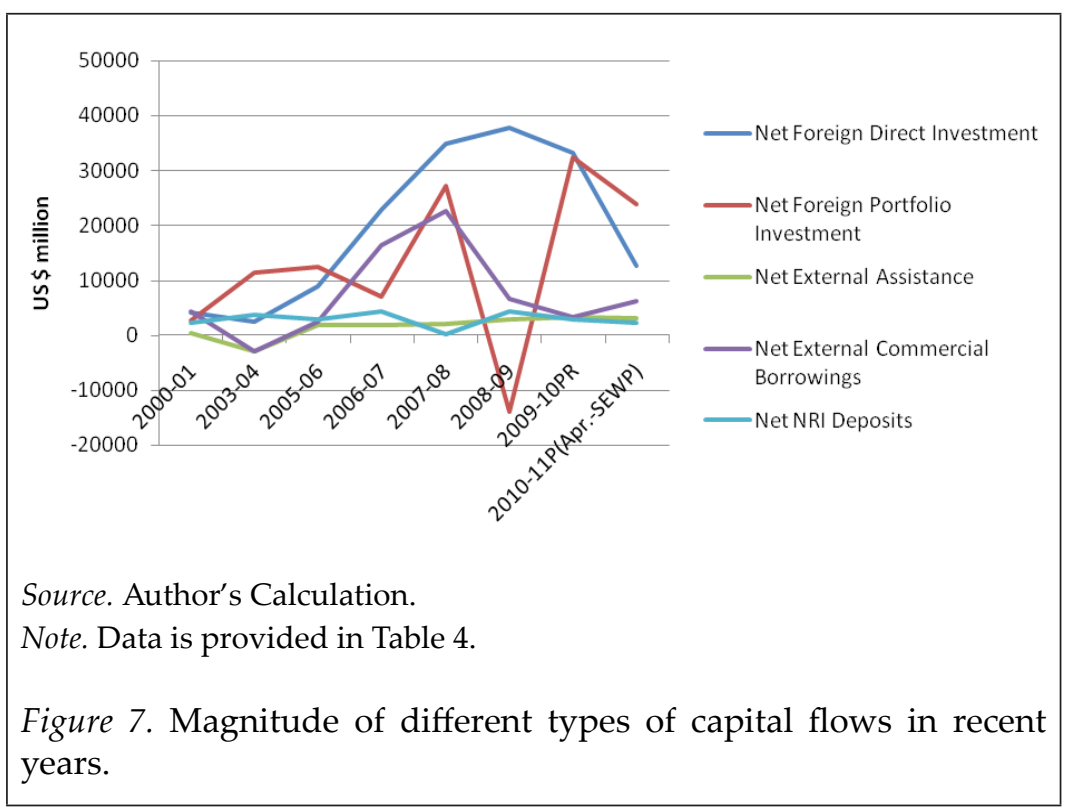

Along with some of the EMEs like Brazil and Korea, India witnessed a greater preponderance of portfolio flows. The preliminary objective of the management of capital flows was to staunch the rapid appreciation of the real exchange rate. Rajan and Subramanian (2005) and Prasad et al. (2007) show that excessive capital inflows could result in rapid exchange rate appreciation which can hurt exports of emerging markets. Even very short-term appreciation can have messing implications in the form of permanent loss of shares in the export market and reductions in manufacturing capacity. Another objective of managing capital flows was to cool overheated asset prices such as stock and real estate. Prasad and Rajan (2008) postulate that in an underdeveloped financial system, foreign capital is likely to be diverted towards easily collateralized and non-tradable investments like real estate, which lead to asset price booms and subsequent busts; disrupting the economy severely. Foreign portfolio investment into shallow equity markets also cause sharp valuation swings and a phenomena of sudden stop or reversal. Moreover, for the capital control measures to be effective and efficient, the asset prices should exhibit a decline or increase at a slower pace than before.

During the early period of globalization, there was a steady flow of net capital, but it gained momentum after 2000. Net flows of FDI and FPI started rising rapidly and other flows viz. net external assistance 
and commercial borrowings and net NRI deposits showed increase, but not as much as the former two. During 2005-06 and 2006-07 FDI showed more than 150 per cent increase and during 2007-08 FPI was dominant over other types of capital flows. But as many studies show that sudden stops or sudden withdrawals are followed by large capital inflow in the form of FPI, 2008-10 showed depression in overall net capital flows. At the end of March 2008, India's foreign exchange reserves, at $\$ 309.7$ billion, provided a cover of 140 per cent to total external debt, though there has been an increase in the shortterm debt in recent years (see Table 4).

\section{Debt Flows}

External commercial borrowings, external assistance, trade credits and the non-repatriable component of NRI deposits constitute the major portion of the external debt in India. During the 1950s and 1960s, external assistance in the form of external aid flows from bilateral and multilateral sources, constituted the major portion of external financing for India. With the emergence of private capital flows, its importance has turned down steadily during the last three decades. The share percentage of external assistance in India's total capital flows fell from 31.2 per cent in 1990-91 to 1.9 per cent in 2007-08. Conversely, India has started extending assistance to other countries, mainly grants and loans for technical cooperation and training. The grant component dominates external aid with a share of over 90 per cent; the major beneficiaries during 2006-2007 were Bhutan, Nepal and Sri Lanka (Mohan, 2009).

Towards the end of the 1970s, as the grant in the aid flows dwindled, the rise in external financing requirements began in the 1980s. Corporates and the government recognised that reliance on external assistance was not favourable, thus commercial borrowings from international capital markets were preferred. The resort to ECBs by Indian corporates, though initiated in the early 1970s, remained modest due to the dominance of granted, non-market based finance in the form of external assistance from bilateral sources and multilateral agencies. ECBs rose significantly in the latter half of 1990, after experiencing some slowdown in the aftermath of the balance of payment crisis, responding to the strong domestic investment demand, lucrative global liquidity conditions, the upgrade of India's sovereign credit rating, lower risk premium on emerging market bonds, and an upward trend of the capital flow to the EMEs. Throughout the course of this period, ECBs constituted about 30 per cent of the net capital 
flows to India. In the late 1990s and the early 2000s, demand for ECBs remained subdued due to a host of factors such as the global economic slowdown, the downturn in capital flows to developing countries and lower domestic investment demand. The beginning of 2003-04 marked the resumption of debt flows to developing countries; the combined outcome of the higher interest rate differential emanating from ample global liquidity and the robust growth expectations and low risk perception towards the emerging markets. Net inflows under ECBs increased from $\$ 2.5$ billion in 2005-06 to $\$ 16.2$ billion in 2006-07 and further to $\$ 22.2$ billion during 2007-08. ECBs contributed to about 20.5 per cent of the net capital flows to India in 2007-08 (Mohan, 2009). Higher ECB withdrawals during the past few years reflect sustained domestic investment demand, import demand, the hardening of domestic interest rates and also the greater risk appetite of global investors for emerging market bonds. The policy on ECBs is kept under constant review and changes are made as needed.

To tap the savings of NRIs employed in oil-rich or oil-exporting countries and overseas corporate bodies, the Reserve Bank formulated special deposit schemes. They were allowed to open and maintain bank accounts in India under these special deposit schemes, which were both rupee- and foreign currency denominated. Although NRI deposits were generally termed as a stable source of support to India's balance of payments through the 1990s, the external payment difficulties of 1990-91 demonstrated the vulnerability that can be associated with these deposits in times of difficulty and drastic changes in the perceptions of such investors. To cope with such difficulties the Reserve Bank has aligned the interest rates on these deposits with international rates and fine-tuned the reserve requirements, user specifications and other concomitant factors influencing these deposits in order to modulate these flows to be consistent with overall macroeconomic management since the 1990s.

The aggregates of India's external debt position is reflected through the steady improvement in India's debt sustainability and liquidity indicators (Figure 8), while the ratio of India's external debt to GDP has declined over the years from 38.7 per cent in 1991-1992 to 17.8 per cent in 2010-2011. The debt service ratio declined from 30.2 per cent to 4.3 per cent during the same period (Graph 9). Various policy measures were undertaken against the backdrop of deteriorating global financial conditions and India's external situation during the year which stimulated debt creating flows in the form of investments by FIIs in debt instruments, NRI deposits and external commercial 
borrowings. Even though such flows are augured as desired for any developing country, their implications were evident in the form of India's rising external debt (see Figure 8). External commercial borrowings, NRI deposits and trade credit together accounted for 77 per cent of the rise in total external debt at end-March 2012 over the level of end-March 2011(RBI, 2012).

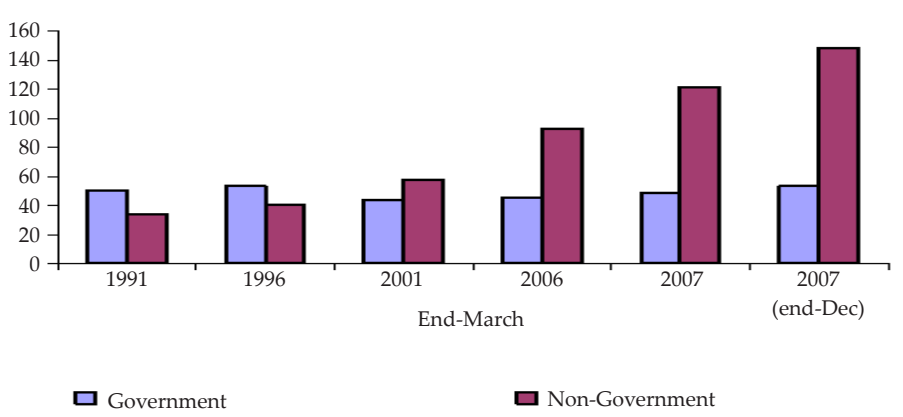

Source. Mohan, 2009.

Figure 8. Government and private external debt outstanding (US\$ Billions).

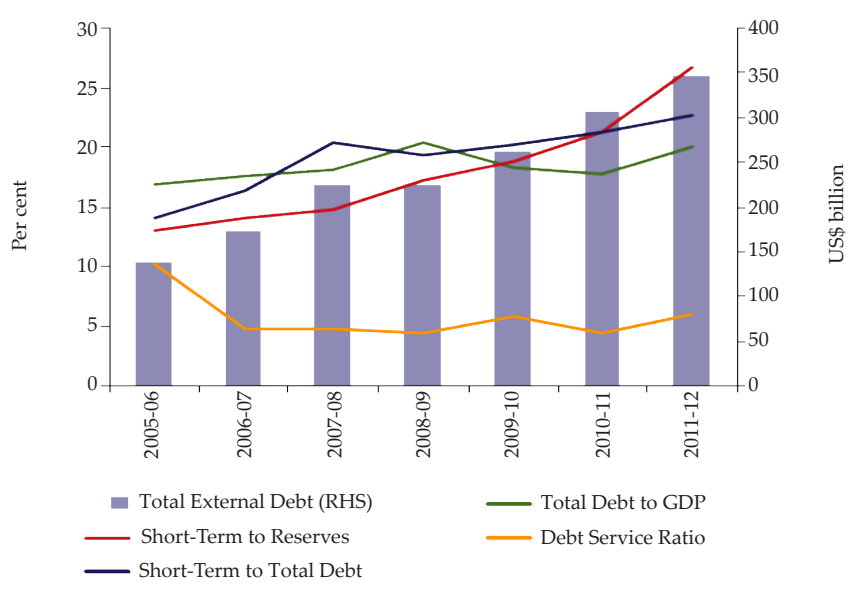

Source. Reserve Bank of India, 2012.

Figure 9. External debt indicators. 


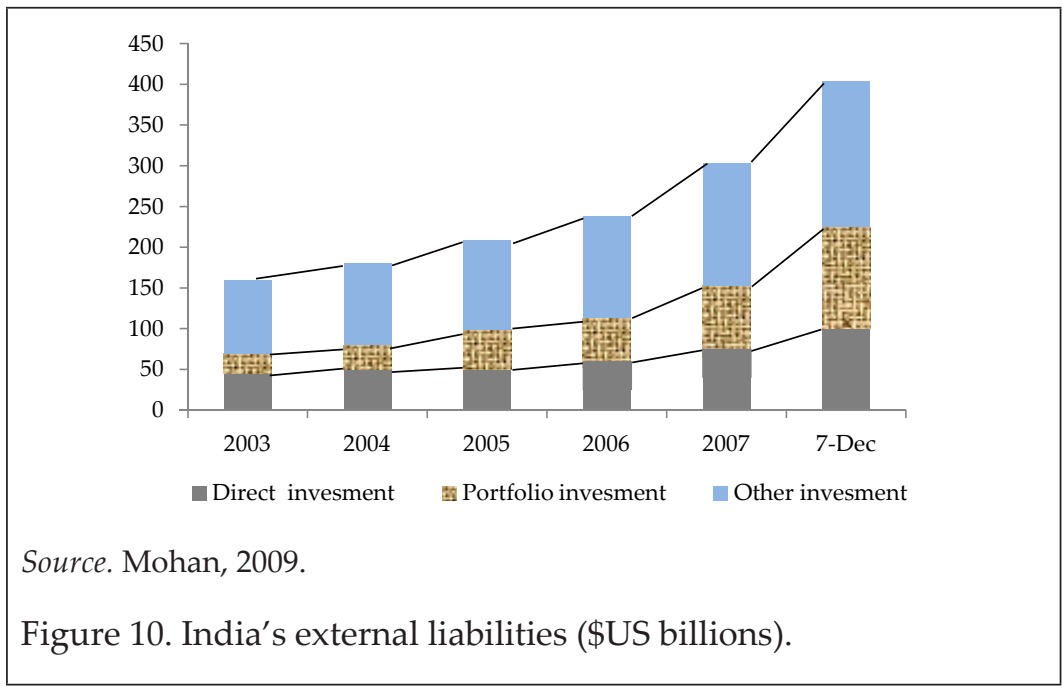

\section{Non-debt Flows}

Foreign direct investments (FDI) and foreign portfolio investments, termed as equity flow, constitute the major forms of non-debt capital flows to India. There has been a marked increase in the size of FDI inflows to India since the early 1990s, reflecting the liberal policy regime and growing investor confidence in Indian economy. India's share in global FDI flows increased from 2.3 per cent in 2005 to 4.5 per cent in 2006. Inflows under FDI were particularly high even during 2008 and 2009, though a large part was offset by significant outflows on account of overseas investment by Indian corporates.

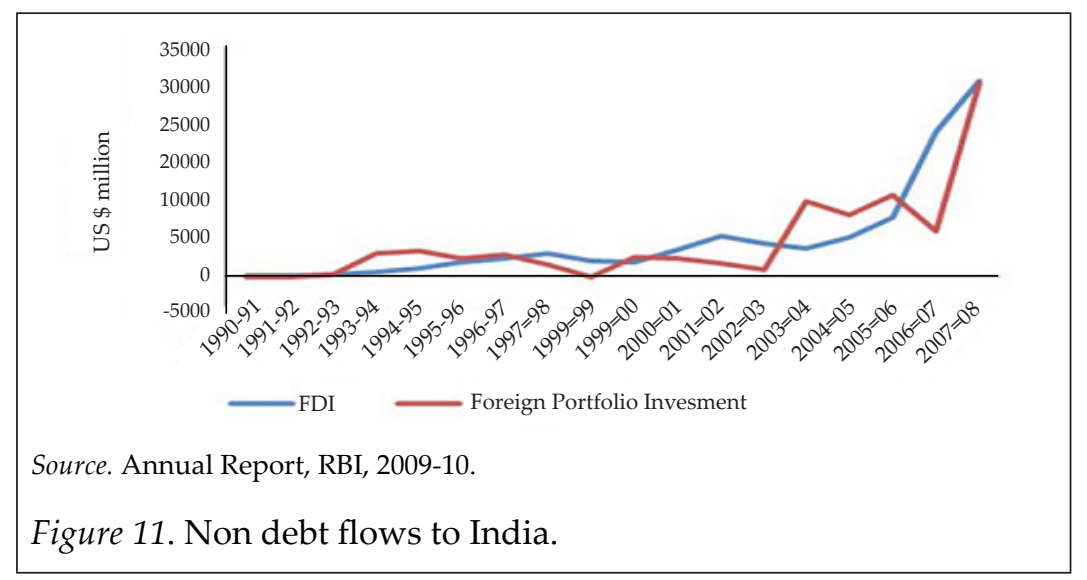


In a major break from the past, the squirt in FDI flows to India in the recent period has been accompanied by a jump in outward equity investment as Indian firms establish distribution, production and marketing networks overseas to achieve global scale along with access to new technology and natural resources. The investment in joint ventures (JV) and wholly-owned subsidiaries (WOS) abroad have emerged as important vehicles for facilitating global expansion by Indian companies. Foreign direct equity investment from India jumped from $\$ 3.8$ billion in 2005-2006 to $\$ 11.3$ billion in 2006-2007 and rose further to $\$ 36.3$ billion during 2009. Overseas investment that started with the acquisition of foreign companies in the IT and related services sector has now spread to other areas such as nonfinancial services.

A pronounced feature of FDI flows to India is that they have been concentrated in the services sector, in demarcation to the dominance of manufacturing in the East Asian economies. This reflects the service-led growth of the economy and its comparative advantage in international trade in services. Another thing that might be mentioned is that IT has enabled greater tradability of a number of businesses and professional services. Due to greater potential for growth in such services sectors, FDI has also emerged as a vehicle to the delivery of services to international markets. Moreover, within the services sector, financing, mutual funds, insurance, banks, real estate and business services witnessed large increases in their shares in FDI flows to India during 2002-2003 and 2007-2008. Computer services remain a key sector for FDI as captive BPO or subsidiaries have been principal instruments for facilitating offshore delivery of computer services and IT-enabled services.

India's share in net portfolio flows to emerging markets and developing countries has expanded in a similar manner to FDI. In contrast to developing and emerging market economies in most parts of the world where FDI has constituted the main source of equity flows, India has witnessed a dominance of portfolio flows over FDI flows during various periods of time. However, not like FDI flows, which exhibited a more or less steady upward trend over the years, portfolio flows are more volatile and disrupting, moving in tandem with domestic and international market sentiments. A sharp rise in portfolio investment into India in the recent period reflects both global and domestic factors. The quest for yield in view of very low real long-term rates in advanced economies has been an important factor driving portfolio flows to EMEs and as a part of that group, 
India also has attracted such flows. Domestic or economy-related factors, such as strong macroeconomic fundamentals, elastic financial sectors, liquid and deep capital markets, better financial performance of the corporate sectors and attractive valuations also attracted large portfolio flows. Consistent with the principle of the hierarchy of capital flows, India is also making efforts towards encouraging more inflows through FDI and enhancing the quality of portfolio flows by strict adherence to the "know your investor" principle (Reddy, 2005).

\section{Managing the Capital Flows}

Ostry et al. (2010) postulate an analytical framework for alleviating decision regarding whether to impose capital controls, holding macroeconomic and financial fragility considerations not only from the individual country's perspective but also taking account of multilateral considerations.

\section{Macroeconomic Implications}

The appropriate policy response is likely to be multifarious, according to the situations facing the country, while answering the questionWhat steps need to be taken while responding to an upsurge in inflow (Figure 12).

Exchange rate appreciation: If the exchange rate is undervalued, the appropriate measure would be allowing the nominal exchange rate to appreciate passively in response to the capital inflows, but when the exchange rate is already overvalued or at least in equilibrium and there are concerns about the impact of an appreciation on competitiveness and deteriorating export conditions, a more proactive policy response is required.

Reserve accumulation: If the country has a relatively low level of foreign exchange reserves from a precautionary perspective and if some further reserve accumulation would be desirable, capital inflows might be considered as a useful opportunity to augment the central bank's reserve holdings.

Sterilization: If there are inflationary concerns, the incidental growth in the money supply can be sterilized through open-market operations through the decrease in domestic credit. But there are, however, some limitations to sterilization. Domestic financial markets may not be 
deep enough to absorb a significant increase in sterilization bonds and there is also a fiscal cost associated with it. Interest paid on domestic bonds and interest earned on reserves, particularly in the current lowyield environment, may be unfavourable to the government. Another facet of sterilization is that domestic interest rates continue to be relatively high, which in turn may attract more inflow from overseas investors and may fuel to economic inflation. To end this vicious cycle, and if central bank does not want to accumulate further reserves, it must try to reduce inflows through macroeconomic policies or more direct methods.

Monetary and fiscal policies: Contrary to sterilization the policy response would be to lower interest rates, thereby reducing incentives for inflows, and to tighten fiscal policy. However, if the economy is at risk of inflationary pressures and overheating, reducing interest rates is not an attractive policy option.

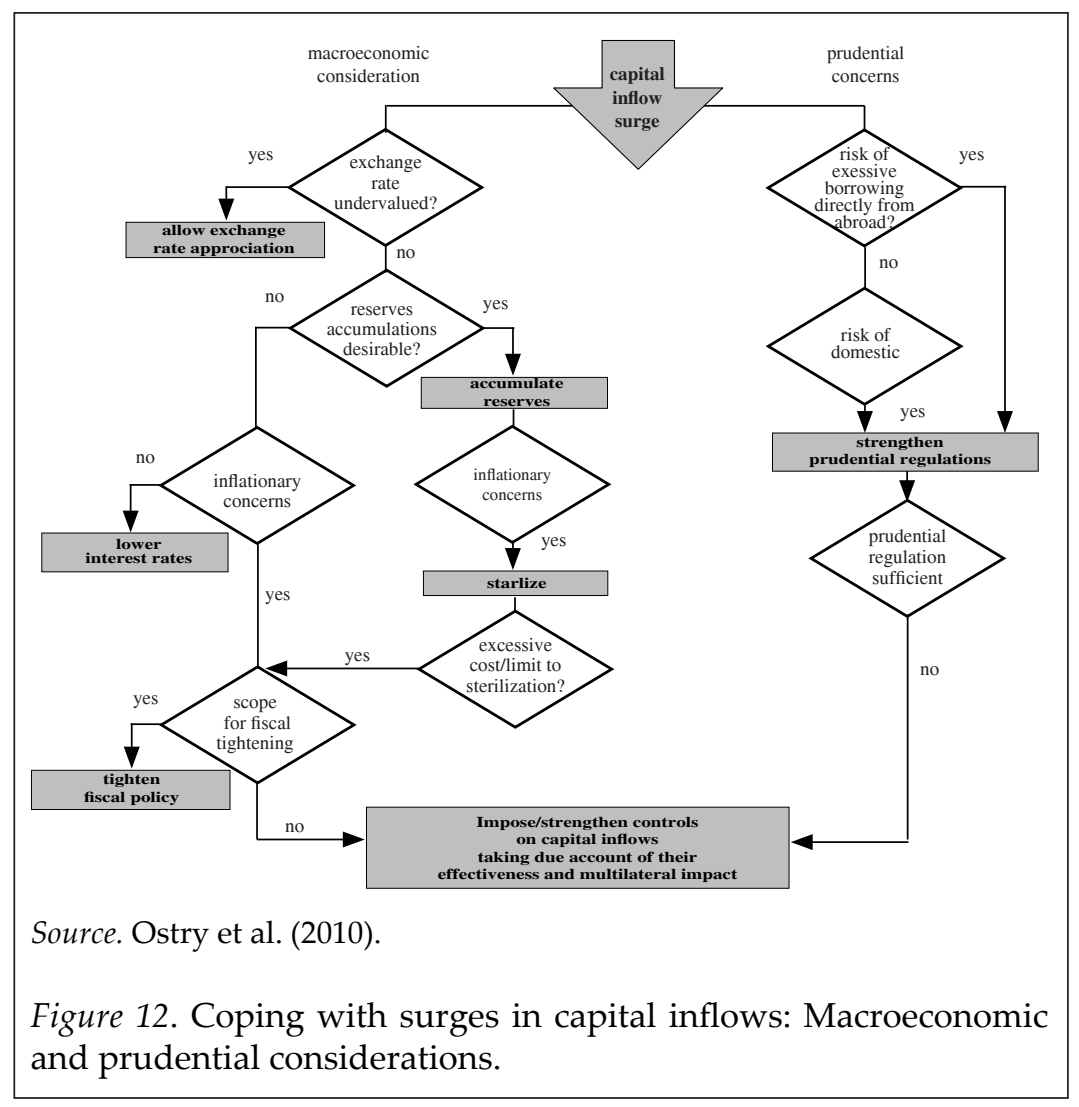


Controls on capital inflows: Keeping in mind the above arguments, in the face of substantial growth in inflows, a pure macroeconomic policy response may not be sustainable in certain circumstances, where controls on capital inflows may prove to be a useful policy toolkit.

\section{Financial Fragility}

The above sections discussed in detail that certain types of capital inflows can make the country more vulnerable to financial crisis. An overt example is debt versus non-debt or equity flows, where the latter permits greater risk sharing between creditors and borrowers. Capital inflows in the form of debt flows might also fuel domestic lending booms including foreign-exchange-denominated credit, which can endanger the position of unhedged borrowers, who underestimate foreign exchange and liquidity risks, making foreign borrowing suboptimal from a financial fragility perspective. Based on these thoughts, the theoretical literature yields a pecking order of capital inflows, in increasing order of riskiness:

1. Foreign direct investment.

2. Portfolio equity investment.

3. Local-currency debt.

4. Consumer-price-indexed local currency debt.

5. Foreign-currency debt.

\section{Other Considerations}

Along with the consideration of the above points, a few other factors need to be considered.

Effectiveness: For the countries, which have substantially closed capital accounts, tightening controls will be easier. But open economies with substantially open capital accounts, need to design and implement new controls and strengthen them at the time of vulnerability, without creating excessive distortions.

Controls on outflows: Relaxing controls on outflows may also prove an efficient tool to manage inflows, which in turn may affect exchange rates and other macroeconomic variables, although the direction of such an impact is unclear. Liberalizing capital outflows can reduce net inflows through off setting effects to inflows. Moreover, greater assurance that capital can be repatriated may make the country an even more attractive destination for foreign investors. 
IJMS 20 (2), (71-104) (2013)

Table 4

Regulatory Framework for Capital Account Management

\begin{tabular}{lll}
\hline & \multicolumn{1}{c}{ Inflow } & \multicolumn{1}{c}{ Outflow } \\
\hline Foreign & FDI is allowed under the automatic & Indian companies and registered \\
Direct & route and government approval & partnerships may invest up to $400 \%$ \\
Investment & route. In several sectors, investment & of their net worth without approval. \\
& up to $100 \%$ is allowed, while a few & The ceiling is not applicable where \\
other sectors have sector-specific the investment is made out of & the \\
caps and guidelines. There are & balances held in the Exchange \\
about 10 sectors in which FDI is & Earners' Foreign Currency account \\
prohibited. & or out of funds raised through \\
& ADRs/GDRs. Lower limits and extra \\
& conditions apply to unregistered \\
& partnership and proprietorship \\
& firms.
\end{tabular}

Portfolio Registered FIIs such as pension The overall limit on residents' Equity funds, mutual funds, investment investments in companies listed Investment trusts etc. and QFIs are allowed abroad is $\$ 200,000$ a year. Resident to invest in equity. The ceilings corporations may invest up to $50 \%$ for overall investment for FIIs of their net worth in shares of listed and QFIs are $24 \%$ and $10 \%$ of the paid-up capital of the company. The ceiling for FII investment Indian Mutual Funds are permitted can be raised up to the sectoral to invest upto an overall cap of $\$ 7$ cap, subject to the approval of billion.

the board and the general body passing a special resolution to that effect. The limit is $20 \%$ of the paid-up capital in the case of public sector banks.NRIs and Persons of Indian Origin (PIOs) can invest in equity up to $10 \%$ of the paid up capital of the Indian company, which can be raised to $24 \%$ subject to the approval of the general body. Holders of Overseas Citizenship of India certificates have the same rights to invest in India as NRIs (except investing in agricultural land). QFIs can invest in those mutual fund (MF) schemes that hold at least $25 \%$ of their assets in the infrastructure sector under the $\$ 3$ billion sub-limit for investment in MFs related to infrastructure. 
IJMS 20 (2), (71-104) (2013)

\begin{tabular}{ll}
\hline \multicolumn{1}{c}{ Inflow } & \multicolumn{1}{c}{ Outflow } \\
\hline Portfolio & Registered FIIs may invest in Only resident individuals may \\
Bond & debt securities issued by Indian invest in debt securities abroad \\
Investments & corporates with an overall subject to a yearly limit of $\$ 200,000$. \\
& limit of $\$ 20$ billion, with an \\
& additional limit of $\$ 25$ billion \\
& in infrastructure bonds and a \\
& $\$ 20$ billion limit on government \\
& securities. The investor base \\
& for G-Secs has been widened \\
& to include SWFs, multilateral \\
& agencies, insurance and pension \\
& funds. Infrastructure bonds have \\
& mandatory holding periods. \\
& Different limits apply to NRIs.
\end{tabular}

Investments Only NRIs may invest in the Indian residents may purchase these in money money market mutual funds.

market instruments abroad without RBI approval.

Derivatives These transactions are generally Commercial banks may purchase subjected to limits and approval. such instruments for their asset Hedging of non-residents' and liability management. Resident investments in India is allowed. companies may use derivatives to hedge commodity price and foreign exchange debt exposures.

Loans ECBs are allowed through the Lending abroad is generally subject automatic and approval route. to approval, except for certain ECBs through the automatic trade credits and lending to foreign route are subject to a cap of $\$ 20$ subsidiaries.

million for a minimum threeyear average maturity and $\$ 750$ million for a minimum five-year average maturity. ECBs through the approval route can be higher than $\$ 750$ million. External loans are subject to an all-in-cost ceiling and end-use restrictions.

Source. IMF (2012) and various RBI and SEBI notifications.

Finally, controls would normally be temporary as a protection to sudden flip-flops. A more permanent increase in inflows tends to stem from more fundamental factors and requires more fundamental economic adjustments.India had adopted a relatively closed capital account policy during most of the post-independence period until the early 1980s. In the second half of the 1980s, a sharp depreciation of the rupee and a widening current account deficit due to higher 
oil prices, raised the demand for external finance. As a result, India resorted to short-term borrowings, external commercial borrowings (ECBs) and deposits by non-resident Indians (NRI). After the balance of payment crisis in 1991, India favoured non-debt flows such as FDI and portfolio investment flows over debt flows. Table 3 throws some light on a few existing measures influencing the inflow and outflow of foreign capital in India. The pattern reveals that in India equity flows have been given preference over debt flows, and within equity flows FDI has been the preferred choice compared to portfolio investments while within debt flows longer-term flows have been preferred over short-term flows.

After 2005, due to excess global liquidity and a strong domestic economy, net capital flows increased four- fold from $\$ 24.9$ billion in 2005-06 to $\$ 107.9$ billion in 2007-2008. The first response of RBI to the surge in capital flows was to accumulate reserves and sterilize the effect of these interventions; the RBI purchased $\$ 26.8$ billion foreign exchange in 2006-2007 and another $\$ 78.2$ billion in 2007-2008, while simultaneously reducing its holding of domestic assets by selling Market Stabilization Bonds (MSBs). The stock of these bonds increased steadily from 373 billion rupees in January 2006 to over 1.7 trillion rupees in October 2007, thus leading the rise in the cost of sterilization due to interest expense. Therefore RBI liberalized the outflow and accelerated monetary tightening through an increase in the repo and reverse repo rate. Rising interest rates attracted further inflows, especially in the form of foreign borrowings by domestic firms; thereby further reinforcing currency appreciation and monetary tightening pressures. In particular, access of corporations to foreign currency funds and conversion of foreign currency loans into Indian Rupees was confined. The ceilings on interest rate for foreign borrowings were reduced. The use of Participatory Notes (PNs), an offshore derivative product, was banned while interest rates on non-resident deposits were also lowered. Despite all the above steps, India's reserve went down by 136 per cent to fund its external debt. This deteriorating reserve cover prompted the policymakers to introduce a host of measures since the second half of 2011; relaxing the restrictions on pricing and quantum of inflows. RBI introduced several key measures to encourage ECBs; deposits by NRIs and FII investment in bond and equity markets. Interest rates on NonResident (External) Rupee (NRE) Term Deposits and Foreign Currency Non-Resident (Banks) (FCNR (B)) deposits were first raised and then completely deregulated. Qualified Foreign Investors (QFIs) were permitted to invest directly in the equity and corporate bond markets. 
The investor base for government bonds broadened. Sovereign Wealth Funds, multilateral agencies, foreign central banks, insurance funds and pension funds were allowed to invest in government bonds. Twoway fungibility in Indian Depository Receipts were allowed subject to a ceiling, and he General Anti Avoidance Rule was deferred to 201314. Greater flexibility in the exchange rate and a more independent monetary policy since 2007 has acted as shock absorber (Abhijit \& Rajeswari, 2012).

\section{Conclusion}

The past decade has been characterized by ongoing financial liberalization in many EMEs, which has resulted in growing linkages and integration among these countries. According to the macroeconomic theory, capital account and financial liberalization should result in a better allocation of savings and more efficient investment, and accordingly in a higher long-run economic growth. To some extent it has resulted in substantial economic and financial benefits, but on the negative side it has also exaggerated the potential harm to global economic conditions. Therefore, even though most of the EMEs now follow better macroeconomic policies than they did before the crises, they are now more vulnerable to external disruptions. Particularly, the recent global crisis has highlighted the fact that financial and capital account liberalization can also result in unfortunate economic outcomes unless accompanied by appropriate regulations and supervision. Sequential arrangements are also important elements to consider while going towards capital account liberalization; certain institutional arrangements need to be in place first along with supervisory and regulatory aspects, and appropriate legal standards that can help maintain financial stability in the presence of capital inflows (Kawai \& Takagi, 2008; McKinnon, 1993). So, the crisis has enlightened widespread interest in tighter regulation of financial markets, financial transactions and financial institutions (Barroso, 2009). Additional regulation, should be implemented in a logical and planned manner, as excessive regulations may not always be the suitable response (Schembri, Santor, \& Epstein, 2009).

The current episode of capital flows in terms of Foreign Institutional Flows to India highlights the importance of the absorption capacity of the capital flows of EMEs. A large surge in capital flows over a short span of time in excess of domestic absorptive capacity of the economy can lead to overheating of the economy, upward pressure 
on exchange rate and asset-price bubbles. They can also pose the risk of sudden reversals or stops, which may have potential negative real economic effects. Given the situation of the low absorptive capacity of India, large capital inflows in excess of a prolong current account deficit are a stress on the real economy through pressures on exchange rate appreciation and sterilization. Real appreciation of the exchange rate leading to the widening of the trade deficit could also lead to a slowdown in economic and industrial growth. This not only affects exporters or overseas business entities, but also affects the profitability of the domestic producers through pressures on domestic prices. Thus, the combination of low domestic absorption and high capital inflows have put forward new challenges for monetary and exchange rate management in India. There is a need for more careful and sensible macroeconomic and external sector policies to keep external sector risks at bay in the near term. The need was aroused especially due to the increase in debt- creating flows over the years. Since the global economic and financial conditions are highly uncertain and dynamic, policymakers need to address risks sprouting from imbalances in India's trade and current account and develop a policy toolkit which is conducive for businesses and boost the confidence of foreign investors.

\section{References}

Abhijit, S. P., \& Rajeswari, S. (2013). Management of capital flows in India: 1990-2011. Munich: Personal RePEc Archive.

Aggarwal, M. R. (2005). Macro economic adjustment, stabilization and sustainable growth in India: Looking back and to the future. India Towards Economic Super Power: A Journey of Economic, 92109.

Barroso, J. M. D. (2009). Declaration on the preparation of the G20 Summit. Speech to the European Parliament, Strasbourg, France, 24 March.

Behind the Stock Market Boom. (1996, April 20-27). Economic \& political Weekly, pp. 979-980.

Bhagwati, J. (2004). In defense of globalization with a new afterword (1st ed.). New York: Oxford University Press.

Clements, B., \& Gupta, S. (2004). Foreign aid: Grants versus loans. Washington: Internatioanal Monetary Fund.

Chandrashekhar, C. P., \& Jayati, G. (2005). The crisis of state government debt. Macroscan. 
Chinn, M., \& Ito, H. (2008). A new measure of financial openness. Journal of Comparative Policy Analysis, 10(3), 307-320.

Davis, D. R., \& Weinstein, D. E. (2003). Market access, economic geography and comparative advantage: An empirical test. Journal of International Economics, 59, 1-23.

Edwards, S. (2007). Capital controls, sudden stops, and current account reversals. In S. Edwards (Ed.), Capital controls and capital flows in emerging economies: Policies, practices and consequences (pp. 73-120). University of Chicago Press.

Kant, C. (2010). Relationship between different types of private capital flows to developing country. Quantitative and Qualitative Analysis in Social Sciences, 4(1), 58-82.

Kaur, M., \& Dhillon, S. S. (2010). Determinants of foreign instituional investors' investment in India. Eurasian Journal of Business and Economics, 57-70.

Kawai, M., \& Takagi, S. (2008). A survey of the literature on managing capital inflows. Asian Development Bank Institute Discussion Paper No. 100.

Keeley, B. (2009). International migration: The human face of globalization. Paris: OECD.

Kohli, R. (2003, February 22-28). Capital flows and domestic financial sector in India. Economic \& Political Weekly, pp. 761-762.

Kose, M. A., Prasad, E. S., \& Terrons, M. E. (2008). Does openness to international financial flows raise productivity growth? Journal of Internatioanl Money and Finance, 28(4), 554-580.

Kumar, R., Palit, A., \& Singh, K. (2007). Sustainability of economic growth in India. The Centre for International Governance Innovation.

Lane, P., \& Milessi-Ferreti, G. M. (2007). The external wealth of nations mark II: Revised and extended estimates of foreign assets and liabilities: 1970-2004. Journal of International Economics, 73(2), 223-250.

McKinnon, R. I. (1993). The order of economic liberalization: Financial control in the transition to a market economy. Baltimore: The Johns Hopkins University Press.

Milesi-Ferretti, G. M., \& Tille, C. (2010). The great retrenchment: International capital flows during the global financial crisis. Centre For Economic policy Research. Paris School of Economics.

Mohan, R. (2008). Global financial crisis: Causes, consequences and India's prospects. London: Bank for International Settlelemts.

Mohan, R. (2009). Capital flows and emerging market economies. Bank of International Settlement.

Ostry, J. D., Ghosh, A.R., Kim, J. I., \& Qureshi, M.S. (2010). Fiscal Space. International Monetary Fund. 
Prasad, E. S. R. Rajan G., \& A; Subramanian, A. (2007). Foreign capital and economic growth. Brookings Papers on Economic Activity, 1.

Prasad, E. S., \& Rajan, R. (2008). A pragmatic approach to capital account liberalization. NBER Working Paper Series. National Bureau of Economic Research.

Rajan, R. G., \& Subramanian, A. (2005). What undermines aid's impact on growth? IMF Working Paper, International Monetary Fund.

Rădescu, O. D. (2008). The process of globalization in the world economy. International University of Moldova.

Reddy, Y. V. (2005). Overcoming challenges in a globalizing economy: Managing India's external sector. Lecture delivered at the Indian Programme of the Foreign Policy Centre, London, 23 June.

Schembri, L. L., Santor, E., \& Epstein, G. (2009). Should financial flows be regulated? In H. Bougrine \& M. Seccareccia (Ed.), Introducing macroeconomic analysis: Issues, questions, and competing views. Toronto: Emond Montgomery Publications.

Siripala, N. S. P. (2003). Sri Lanka: Borrowing capacity assessment. Asian Development Bank.

Sullivan, A., \& Sheffrin, M. (2003). Economics: Principles in action. New Jersey: Pearson Prentice Hall.

(2000). Debt and reserve related indicators of external vulnerability. IMF.

(2001). The challenge of maintaining long-term external debt sustainability. World Bank, IMF.

(2001). Trade policies, developing countries, and globalization. World Bank.

(2002). Globalization, growth and poverty. Washington, DC.: World Bank and Oxford University.

(2003). External debt statistics: Guide for compilers and users. IMF.

(2005). Global development finance: Mobilizing finance and managing vulnerability. World Bank.

(2008-2009). Annual Report. Reserve Bank of India.

(2009-2010). Annual Report. Reserve Bank of India.

(2010-2011). Annual Report. Reserve Bank of India.

(2010-2011). Union budget and economic survey. Govt. of India.

(2011-2012). Annual Report. Reserve Bank of India.

(2011). World economic outlook. IMF.

(2013). World economic outlook. IMF. 